\title{
La interculturalidad cooperativa
}

\author{
Tulio Rosembuj Erujimovich
}

Universidad de Barcelona

De la inmigración hay una visión buena y otra mala. El buen discurso apela a la multicultura, una expresión acrítica de tolerancia, de pluralismo, de desprejuicio. Bienvenidos los que llegan, de cualquier parte, que nos harán mejores. Es la expresión inocente de la diferencia, la pantalla velada que difumina la realidad social, un atajo para justificar la riqueza, con tutela policial y guardias de frontera. El privilegio no es para los que se quedan, sino para los que consiguen entrar, aun a riesgo de su vida. El buen discurso está en crisis. No para menos. Hay demasiadas personas que consiguen entrar, agrupándose en familias, en barrios, por color, por nacionalidad y, el colmo, incluso por religión. Son tantos que han dejado de ser invisibles. Se ven en todas las esquinas, en cada calle, en cualquier ciudad. Esto es un aluvión.

El discurso malo nace del temor, de la inseguridad, en suma, de la presencia multitudinaria de personas diversas. El desorden, la acumulación de conflictos, la degradación de la ciudad, de los barrios, de las calles. Y, sobre todo, la inseguridad y la amenaza de otras lenguas, de otros colores, de otros ritos. La prohibición de entrada no sirvió de gran cosa. Deben construirse muros en la tierra, en el agua, en el aire. Y devolver a los afortunados que los traspasan a sus paises de origen. ¿Donde van a estar mejor que en su casa? Pero, además, tolerancia cero con sus costumbres, que son bárbaras y cerriles y reproche firme a las creencias que, finalmente, son caldo de terrorismo.

El discurso malo es el de los ricos amenazados. El único inmigrante deseado es el esclavo.

1. Ni la versión buena ni la mala tienen razón. La inmigración de masa es antes que nada un fenómeno de renta. Siempre hay un país próximo donde la vida puede ser mejor. Así lo vivieron los europeos a comienzos del siglo xx yéndose a hacer las Américas y los españo- 
les, italianos, portugueses en los sesenta encaminados hacia Alemania, Francia o Suiza. Pero, no seamos hipócritas, iban a buscar dinero, pero, además, esos paises necesitaban mano de obra, calificada o no, barata. Lo uno por lo otro. Te pago menos a cambio de trabajo. La explotación del país hombre por el hombre.

La diferencia ahora es la información en tiempo real (o, mejor aún, la televisión). El estímulo es acceder a «El Corte Inglés» o equivalente. La sociedad rica del espectáculo exacerba a los pobres y les hace aspirar a su participación, cualquiera que sea su lugar geográfico, lengua de origen o denominador histórico. Uno llega a «El Corte Inglés» de Suecia, de Francia, de España, de Italia. El consumo de masa es el común denominador. Esto no es criticable, al fin y al cabo, es lo que hacemos los del lugar de origen. Lo que verdaderamente molesta es que se crean iguales, aunque sean diferentes. No todo se reduce a pasar por caja. Hay más cosas en la mente de las personas (el futbol, el sexo, el dinero, aunque no en este órden). Pero, eso es lo que tiene el consumo que nos iguala en la cola de la caja. El inmigrante pobre cree que todo es un Corte Inglés.

2. El inmigrante es un explorador solitario, desguarnecido en medio la hostilidad que le rodea. Trabaja como el que más, pero necesita sentir la compañía de su familia, de sus amigos, de sus connacionales y correligiosos. Apenas instalado promueve la socialidad hacia fuera, porque dentro las puertas se cierran con la jornada de trabajo. Y no puede circular por cualquier sitio, no solo porque es pobre, sino para que la policía no le detenga en cualquier momento por sospechoso habitual de color negro, de origen marroquí, de tez aceitunada y origen sudamericano.

Si trabajar cansa, el cansancio del inmigrante suena a infinito. Claro que esto tiene su compensación. Su familia de origen espera ansiosa la remesa mensual. Hay paises enteros cuya renta per capita está sobre los hombros del inmigrante, que no de los locales. O sea, ayudan a que en su lugar de origen, simplemente, puedan sobrevivir.

3. Es cierto que la inmigración supone un incentivo al tráfico ilícito de personas. Hay un cúmulo de criminalidad organizada que tiene otro negocio en la circulación de personas. Siempre que hay una prohibición surgen los que propician su violación por un precio que será más o menos alto conforme al riesgo que se corre. Las mafias hacen un gran negocio con Europa. A más restricciones, más beneficios. 
Hay daños colaterales, víctimas del tráfico, que es insignificante en comparación con el volumen de éxito conseguido. La inmigración, según datos de las Naciones Unidas, suma entre 3 y 4 millones de personas indocumentadas por año, lo que supone para los organizadores algo así como 10 billones de dólares. Pero, no sólo. Serán mano de obra ilegal para otros negocios ilícitos, tales como transporte de drogas, piratería, falsificación de artículos de consumo, CD, etcétera (modern days slaves). Y, en su caso, todo hay que decirlo, terrorismo de cuño fundamentalista.

4. La interculturalidad es un esfuerzo serio para superar la visión angélica del inmigrante. Una aproximación de los lugares de recepción para establecer vías de comunicación con personas que son distintas. Esto supone un esfuerzo para entender, para comprender, para facilitar la estancia. Es decir, un lenguaje, unas competencias, unas habilidades para aproximarse al otro. Eso sí, respetando sus costumbres, sus creencias, sus ritos y mitos. No hay una idea de caridad o de compasión, sino de organización social, cultural, política, que aspira a fijar derechos y obligaciones recíprocas, mientras dure la convivencia. No hay nada fuera de su persona que les una al país huésped. Por duro que sea, les importa un pito su historia, lengua, tradición. Estan aquí porque no tuvieron otro remedio. Sale de su país cojo, buscando una prótesis, que les permita el sueño del retorno. Ningún inmigrante viene a quedarse. Se juega la vida para volver. Una objetivización del inmigrante podría ser la de un transeúnte al que se le ofrece cobijo, alimento, salud, educación y salario, en tránsito hacia su tierra. Muchos preferirán quedarse, pero, seguramente, no lo saben y en sus sueños, sueñan con el paraíso perdido que no es donde se encuentran.

5. Hace mucho que no se habla de la cooperativa cuando se habla de problemas globales. Hace tiempo que el cooperativismo dejó de ser una oferta de solución de conflictos. La cooperativa se ha hecho invisible ante los problemas reales de masa, sean medio ambientales, de inmigración, de mediación cultural. Y es paradójico que así sea, porque no hay, en la historia, una institución que mejor se preste, se adapte a la resolución de disputas de masa. Lamentablemente, su puesto está mejor desarrollado por las ONG u otras entidades sin ánimo de lucro que cogieron el relevo.

Si ahora la cooperativa no fuera invisible tendría una fuente inagotable de cumplir con la ayuda mutua y recíproca. Imaginemos, por 
un momento, que la intercultura es propósito de la mediación cultural cooperativa; que el trabajo es objeto del cooperativismo de trabajo asociado; que la asistencia técnica, formativa y profesional es ocupada por la cooperativa de servicios o de enseñanza o que las remesas se cursan desde la de crédito y asimismo los préstamos y anticipos para vivienda, viajes, etcétera.

Tristemente no es así. No hay nada que vincule la interculturalidad con la cooperativa, que es como decir que nada liga la cooperativa con el inmigrante. En los ochenta Marcus definía el caring for others como la idea central del movimiento cooperativo.

En el siglo XxI la cooperativa de los países ricos parece ensimismada en su propio ombligo, autosatisfecha de su resistencia y reticencia a los desafíos globales. Lo pagará muy caro, porque, como es de su definición, no puede predicarse lo que no se tiene. 